\title{
A Histological Assessment of the Cell Death Induced by Haloperidol on Prefrontal Cortex
}

\author{
Una Evaluación Histológica de la Muerte Celular \\ Inducida por Haloperidol en la Corteza Prefrontal
}

Ali Ghanbari"; Seyran Kakebaraei** \& Mozafar Khazaei***

KAKEBARAEI, S.; KHAZAEI, M. \& GHANBARI, A. A histological assessment of the cell death induced by haloperidol on prefrontal cortex. Int. J. Morphol., 31(4):1439-1443, 2013.

SUMMARY: Neuroleptic drugs such as haloperidol has side effects on extrapyramidal pathways. Tardive Dyskinesia is the most important complication. The most characteristic feature of this Tardive Dyskinesia is involuntary movements of mouth and face. In regard to this problem, the induction of gliosis and cell death in the nervous tissue are considered. In this study, adult Sprague-Dawley rats were used as experimental models. Rats were divided into control and experimental groups. The rats were kept in the animal house under standard conditions during experiments. The control rats were intraperitoneally treated with normal saline for 6 days. The experimental samples were treated for the same time with 2,5 and $10 \mathrm{mg}$ haloperidol. After the trial period, the rats were killed following general anesthesia and their brains were removed after perfusion with a $4 \%$ formalin solution. Then, 1 mm cuts of the brains were obtained. After that, $5 \mu \mathrm{m}$ tissue sections were prepared and stained with hematoxylin and eosin. The stained sections were examined by optical microscopy. The results showed that the short-term use of haloperidol does not lead to gliosis process in the rat cerebral cortex. The short-term use of $10 \mathrm{mg}$ haloperidol results in cell death in the rat cerebral cortex. Cell death was not observed in the control group and the groups that had received $2 \mathrm{mg}$ and $5 \mathrm{mg}$ doses of haloperidol. According to previous studies, it can be concluded that the gliosis process is induced in the cerebral cortex only following the long-term use of haloperidol. It is considered as a secondary cause of the neuroleptic drugs side effects. The primary cause of these side effects is the induction of cell death in neurons.

KEY WORDS: Haloperidol; Cerebral cortex; Optical microscopy; Cell death; Rat.

\section{INTRODUCTION}

The neuroleptic drugs which are used in the treatment of neurological diseases have side effects on extra pyramidal pathways. The neuroleptic drugs exert their pharmacological effects through extrapyramidal dopamine receptor-mediated inhibition including Tardive Dyskinesia. However, they also affect other neurotransmitter systems (Post et al., 2004).The dopamine system exists in many regions of the brain including dark matter, striatum, hippocampus and cerebral cortex (Noh et al., 2000). Since rats and primates show same involuntary movements of mouth and face as human in response to neuroleptic drugs, and due to moral limitations on human, these species are used as valuable models to improve the knowledge about the cause of Tardive Dyskinesia (Noh et al.). Haloperidol is considered a typical neuroleptic drug which is widely administered.
Haloperidol is a dopamine receptor blocker. Tardive Dyskinesia is considered as one of its side effects. The involuntary movements of mouth and face are the most common symptom of this disease. The mechanism of this irreversible complication on the nerve cells is not completely understood yet (Gale, 1980). One of the major mechanisms in the incidence of medications side effects is cell death induction. Two types of cell death including apoptosis and necrosis have been known.

Some authors believed that haloperidol causes necrosis cell death in neurons (Behl et al., 1996). But recent studies show that haloperidol leads to increasing dopamine production in pre-synaptic neurons. This in turn causes increased glutamate levels in the post-synaptic neurons.

\footnotetext{
* Fertility and Infertility Research Center, Kermanshah University of Medical Sciences, Kermanshah, Iran.

** Student Research Committee, Kermanshah University of Medical Sciences, Kermanshah, Iran.
} 
GABA, and other oxidants and decrease of neurotransmitters and the resultant changes induce apoptotic cell death in neurons (Noh et al.).

The other mechanisms leading to apoptosis include activation of $\mathrm{d} 2$, JNK receptors in neurons that is triggered by haloperidol. In general, the oxidative stress induced by haloperidol is considered as a part of the process of neuronal damage by this drug (Post et al., 2004; Behl et al., 1995; Gale; Wei et al., 2006).

The previous studies on rats show that the long-term use of haloperidol leads to increase of the volume of cerebral ventricles, atrophy and gliosis (Gale) in wide areas of the brain including the hippocampus, dark matter and Accumbans striatum. It also reduces the number of dendritic spines and synapses of the nucleus.

Some other studies have shown that the long-term use of haloperidol causes damage to the nervous pathways. Thus, haloperidol can cause damages to the white tissue of the brain and nigrostriatal Pathway as well (Licht et al., 1994; Dalgalarrondo \& Gattaz, 1994; Roberts et al., 2002; Meredith et al., 2000).

The short-term use of haloperidol induces apoptosis in the striatum and dark matter neurons of rats (Mitcheel et al., 2002) while causes no cell death in the rat cerebral cortex (Gil-ad et al., 2001). Also, the use of haloperidol causes apoptosis induction in neurons which have been isolated in vitro from the cerebral cortex (Wei et al.).

Although the cellular damage of haloperidol on rat cerebral cortex has been demonstrated in vitro conditions, no evidences were found on either apoptosis or necrosis cell death induction in the cerebral cortex of rats following administration of haloperidol. The present study was conducted in order to address the contradictions on the effect of haloperidol on the cerebral cortex. The objective of the present study is to investigate the histological properties of rat cerebral cortex following administration of haloperidol.

\section{MATERIAL AND METHOD}

Materials. Experiments were performed on adult SpragueDawley male rats with an average weight of $250 \mathrm{~g}$ (at the beginning of experiment). Animals were kept in a colony room with a constant temperature $\left(25 \pm 2^{\circ} \mathrm{C}\right)$, humidity $(70 \pm 5 \%)$ and artificial 12:12 h light-dark cycle. The lights were turned on at 07:00 am. Animals were kept in individual cages with wood-chip bedding and had free access to standard food and water. All experiments in this study were performed in accordance with the ethical guidelines set by the "Ethical Committee of Faculty of Medical Sciences, Kermanshah University of Medical Sciences," which completely coincides with the "National Institutes of Health Guide for the Care and Use of Laboratory Animals.' All experiments were conducted during the same time of day (10:00 am to 06:00 pm).

The General Procedures of the Experiments. The animals received three doses of 2, 5 and $10 \mathrm{mg}$ of haloperidol or vehicle drug ( $9 \%$ normal saline) for 6 consecutive days. Rats were deeply anesthetized with chloroform $24 \mathrm{~h}$ after the last injection. The total volume of the brain was removed following perfusion with $10 \%$ formalinin normal saline.

Coronal sections with a diameter of $1 \mathrm{~mm}$ were randomly prepared of the total volume of brains. After the usual tissue preparation procedures, $5 \mu \mathrm{m}$ sections were prepared by the microtome. The sections were stained with hematoxylin and eosin and were examined by optical microscopy.

Five different points were randomly selected for histological observation in each section. The apoptotic and normal cells of the brain slides of control and experimental groups were studied.

Neurological-Behavioral Observations. After injection of haloperidol or Vehicle, the neurological and behavioral changes including agitation, withdrawal, and involuntary movements of jaw and face were controlled for $1 \mathrm{~h}$, after 24 $\mathrm{h}$ and prior subsequent injections.

TUNEL Assay. Brain cell apoptosis was assessed by terminaldeoxynucleotidyltransferase (TdT)-mediated deoxyUTP nick end labeling (TUNEL) assay using ApopTagalkaline phosphatase in situ Apoptosis Detection kit (Roche;11684809910), according to the manufacturer's instructions.

Following TUNEL staining, sections were counter stained with Harris Hematoxylin and mounted under glass coverslips. The sections were examined and scored under a light microscope (Nikon; YS100) equipped with a digital camera (Motic) (400X). Apoptotic index was the ratio of TUNEL positive cells to negative ones and for this purpose sections from 10 animals per group in at least 5 random fields per brain were analyzed. As negative controls, a section from each animal was processed, but terminal transferase was omitted from the TdT labeling buffer and for positive controls DNAse was added on the sections (Hsu et al., 2001). 


\section{RESULTS}

The results were obtained by investigation of histological slides of adult rat cerebral cortex using an optical microscope. The slides in the control and experimental groups were prepared from all regions of the cerebral cortex.

The gliosis process does not occur in adult rat cerebral cortex following the short-term use of haloperidol. The results show that the morphology of the cerebral cortex in the control group is similar to groups which received $2 \mathrm{mg}$ and $5 \mathrm{mg}$ haloperidol. As can be seen in Figure 1, in all sections, neurons and supporting cells can be seen naturally together. Morphologically, the supporting cells and neurons are not similar. Also, the aggregation of supporting cell is not observed and the cells are located with a natural distance from each other.

No changes were observed in the morphology and aggregation of supporting cell in all sections of the cerebral cortex of adult male rats treated with $10 \mathrm{mg}$ haloperidol (Fig. 1B). Thus, none of the haloperidol doses will change the morphology of supporting cells. Furthermore, the gliosis process that is characterized by the accumulation of supporting nerve cells is not occurred in the rat cerebral cortex following the use of haloperidol.

The short-term use of haloperidol with a dose of 10 $\mathrm{mg}$ causes apoptosis in the cerebral cortex neurons of adult rats.
Assessments of the slides of the study and control groups reveal that some neurons in the experimental group who have received a $10 \mathrm{mg}$ haloperidol have more dense nuclei. The images with higher magnifications demonstrate that the nucleus is being fragmented. Fragmentation and condensation of the nuclei occurs during the apoptosis process (Fig. 1B). This data was confirmed by stained cells with TUNEL in this group (Fig. 1D). This has been seen before in the case of dark matter and striatum neurons following administration of haloperidol. Given that apoptosis occurs within 1-2 h, some apoptotic cells are lost during the process and cannot be observed by optical microscopy. The apoptotic neurons are observed in all cerebral cortex sections of the group that received $10 \mathrm{mg}$ haloperidol. It is therefore likely that the short-term use of haloperidol reduce the size of the rat cerebral cortex. Therefore, it is recommended that in future studies on the effects of neuroleptic drugs on the cerebral cortex, stereological methods would be used to determine the impact of changes resulting from the use of such drugs.

\section{DISCUSSION}

One of the most important cellular events in response to pathological conditions of the brain is the process of gliosis. Microglial cells and astrocytes have an essential role in the formation of gliosis process. The response of astrocytes to a situation includes the increase of the number and size and production of GFAP pathological protein. The

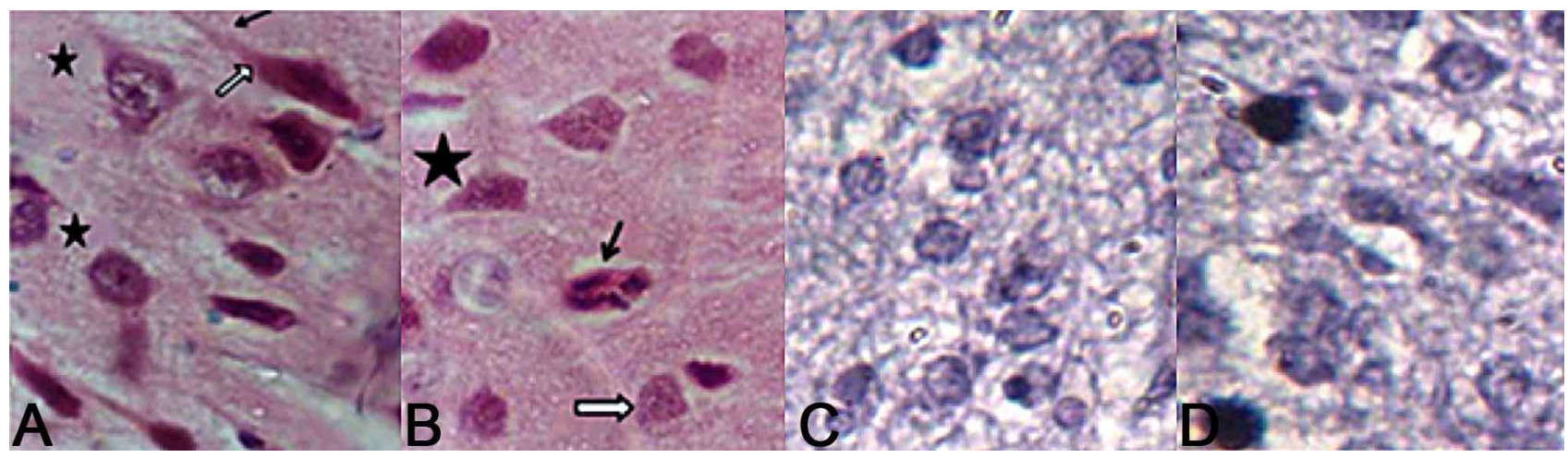

Fig. 1. The optical microscope image of the cerebral cortex of adult rats with a magnification of X400. The sections stained with H\&E (A, B) or TUNEL mixture (C, D). A: collection of supporting nerve cells with bright nucleus and cytoplasm are observed (Stars). The neurons are observed with a more dense nucleus and cytoplasm. Also, the location of the leaving the axon of a neuron terminal and axon hills can be seen (Black and white arrows). The same morphology was seen in all sections in the experimental groups treated with 2 mg and $5 \mathrm{mg}$ haloperidol. B: in the group treated with $10 \mathrm{mg}$, a collection of supporting nerve cells with bright nucleus and cytoplasm are observed (White arrow). Also, neurons with more dense nucleus and cytoplasm as well as the location of the leaving the axon of a neuron terminal and axon hills can be seen (star). It seems that the nucleus of a neuron is becoming denser and dividing into four parts (Black arrow). C: TUNEL staining of cerebral cortex of control adult rats and also in $2 \mathrm{mg}$ and $5 \mathrm{mg}$ haloperidol treated groups. D: TUNEL staining of cerebral cortex of $10 \mathrm{mg}$ haloperidol treated adult rats showed that some of the cells stained with dark blue appearance. 
biochemical stimuli that lead to activation of astrocytes are derived from neurons and microglial cells so that the production of glutamate, glucose and free radicals in neurons and production of interleukins in microglial cells activate astrocytes. The activated astrocytes result in production of amyloids and cytokines which in turn may increase the damage to neurons (Druga et al., 2003).

The long-term effects of environmental factors may induce the gliosis process in the rat cerebral cortex similar to the use of therapeutic doses of certain drugs and oxygen deficiency during which astrocytes are seen as cells collections in the cerebral cortex (Licht et al.; Roberts et al.). However, the short-term effects of these environmental factors in higher doses do not induce the gliosis process in the rat cerebral cortex (Marín-Padilla, 2000).

Similarly, the short-term effects of higher therapeutic doses of haloperidol do not induce the gliosis process in the dark matter and striatum of the rat brain following in vitro removal of cerebral cortex cells. The other studies have also shown that the haloperidol does not affect the number and size of the supporting tissue cells (Meredith et al.; Gil-ad et al.).

In the present study, the short-term use of haloperidol was administrated at doses higher than the therapeutic dose. The comparison of the slides prepared from the brains of rats in the control and experimental groups showed no changes in the status of supporting tissue cells. Therefore, the present study also confirms that the short-term use of the haloperidol do not induce the gliosis process in the cerebral cortex of rats. Given that the studied animals showed the clinical symptoms of Tardive Dyskinesia following haloperidol administration and since the gliosis process was not observed in brain section of rats in experimental groups, it can be concluded that the gliosis process is not considered as the main cause of Tardive Dyskinesia as the haloperidol side effect. Since Tardive Dyskinesiais caused following damage to neurons, it can occur as a secondary factor due tolong-term use of haloperidol. The studies on long-term use of haloperidol have shown that the gliosis process is induced following damage to the cerebral cortex neurons.

In the case of damage to neurons, the administrated dose should also be noted in addition to the duration of exposure to environmental factors. It was shown that Tardive Dyskinesia occurs using a dose of $2 \mathrm{mg}$. The effect on haloperidol on the behavioral changes in the tissue slices of the cerebral cortex of experimental and control groups are the same in accordance to neuronal morphology. However, the same dose of haloperidol results in cell damage of apoptotic cell death in some regions of the brain such as the striatum and dark matter. The studies have shown that the amount of antioxidants in these two regions of the brain is much lower than other regions such as the cerebral cortex (Mitcheel et $a l$.). Since the primary mechanism of apoptosis caused by the haloperidol is the oxidative stress due to production of free radicals and also given that in order to eliminate oxidative stress, the amount of enzymes and antioxidants in the cerebral cortex is higher than the dark matter and the striatum, it can be concluded that the lack of observed differences in the morphology and number of cortical neurons following the use of haloperidol is due to larger amount of antioxidants in the cerebral cortex.

Perhaps this is why the other studies have claimed that despite the side effects by using low doses of haloperidol, it does not cause damage to the cerebral cortex. This is while haloperidol induces apoptosis in cortical neurons due to higher production of oxidizing agents in a dose of $10 \mathrm{mg}$. The studies also indicated that antioxidants such as vitamin $\mathrm{E}$ and $\mathrm{C}$ can reduce cell damage induced by haloperidol (Behl et al., 1996; Post et al., 2002).The simultaneous use of antioxidants is important so that the simultaneous use of dopamine and haloperidol does not reduce the cell damage caused by the haloperidol (Gil-ad et al.). Therefore, it is recommended that the amount of antioxidants and antioxidant enzymes in brain tissue is evaluated in addition to histological examination of the effects of neuroleptic drugs. Also, antioxidants like vitamin $\mathrm{C}, \mathrm{E}$, selenium and zinc can be used to reduce tissue damage caused by neuroleptic drugs.

Considering the findings of the study, it can be concluded that long-term therapeutic doses of haloperidol and short-term haloperidol doses well above the therapeutic dose cause same clinical complications. But they have different cellular effects. The short-term use of haloperidol induces the apoptosis cellular damage to the cerebral cortex only at doses higher than the therapeutic dose. This may be due to the high amount of antioxidants in the brain cortex. It is also proposed that it may be due to lower levels of the antioxidants in dark matter and the striatum compared to brain cortex. At low doses, haloperidol causes apoptosis in neurons in these two brain nuclei.

In general, the cause of Tardive Dyskinesia side effect is the apoptosis cell death induction caused by the haloperidol. It induces the same process in the cerebral cortex at higher doses. It is suggested that in future studies, the antioxidants would be used to reduce the side effects of such drugs.

ACKNOWLEDGEMENT. This work is supported as a grant (no. 92006) for MSc. degree from Kermanshah University of Medical Sciences. 
KAKEBARAEI, S.; KHAZAEI, M. \& GHANBARI, A. Una evaluación histológica de la muerte celular inducida por haloperidol en la corteza prefrontal. Int. J. Morphol., 31(4):1439-1443, 2013.

RESUMEN: Los fármacos neurolépticos como el haloperidol tiene efectos secundarios sobre las vías extrapiramidales. La discinesia tardía es la complicación más importante. El rasgo más característico de esta discinesia tardía son movimientos involuntarios de la boca y cara. En lo que respecta a este problema, se consideran la inducción de gliosis y muerte celular en el tejido nervioso. En este estudio, fueron utilizados ratas Sprague - Dawley adultas como modelos experimentales. Las ratas se dividieron en grupos control y experimentales, y se mantuvieron en condiciones estándar durante los experimentos. Las ratas control fueron tratadas por vía intraperitoneal con solución salina normal durante 6 días, y las experimentales durante el mismo tiempo con 2, 5 y $10 \mathrm{mg}$ de haloperidol. Luego, las ratas se sacrificaron y sus cerebros se extrajeron después de la perfusión con una solución de formalina al $4 \%$, obteniendo cortes de $1 \mathrm{~mm}$ de los cerebros. Se prepararon y se tiñeron con hematoxilina y eosina en secciones de tejido de 5 micras, y se examinaron por microscopía óptica. Se observó que el uso a corto plazo del haloperidol no conduce a proceso de gliosis en la corteza cerebral de rata. El uso a corto plazo de $10 \mathrm{mg}$ de haloperidol produjo muerte celular en la corteza cerebral de rata. La muerte celular no se observó en el grupo control ni en los grupos que habían recibido 2 y $5 \mathrm{mg}$ de haloperidol. De acuerdo con estudios anteriores, se concluye que el proceso de gliosis se induce en la corteza cerebral sólo tras el uso a largo plazo de exposición al haloperidol. Se considera como una causa secundaria de los efectos adversos de los fármacos neurolépticos. La principal causa de estos efectos secundarios, es la inducción de muerte celular en neuronas .

PALABRAS CLAVE: Haloperidol ; Corteza cerebral; Microscopía óptica; Muerte celular; Rata.

\section{REFERENCES}

Behl, C.; Lezoulac'h, F.; Widmann, M.; Rupprecht, R. \& Hoslboer, F. Oxidative stress-resistant cells are protected against haloperidol toxicity. Brain Res., 717(1-2):193-5, 1996.

Behl, C.; Rupprecht, R.; Skutella, T. \& Holsber, F. Haloperidol-induced cell death-mechanism and protection with vitamin E. in vitro. Neuroreport, 7(1):360-4, 1995.

Dalgalarrondo, P. \& Gattaz, W. F. Basal ganglia abnormalities in tardive dyskinesia. Possible relationship with duration of neuroleptic treatment. Eur. Arch. Psychiatry Clin. Neurosci., 244(5):272-7, 1994.

Druga, R.; Kubová, H.; Suchomelová, L. \& Haugvicová, R Lithium/ Pilocarpine Status Epilepticus-Induced Neuropathology of Piriform Cortex and Adjoining Structures in Rats is AgeDependent. Physiol. Res., 52(2):251-64, 2003.

Gale, K. Chronic blockade of dopamine receptors by antischizophrenic drugs enhances GABA binding in substantia nigra. Nature, 283(5747):569-70, 1980.

Gil-ad, I.; Shtaif, B.; Shiloh, R. \& Weizman, A. Evaluation of the neurotoxic activity of typical and atypical neuroleptics:relevance to iatrogenic extrapyramidal symptoms. Cell Mol. Neurobiol., 21(6):705-16, 2001.

Hsu, H. K.; Yang, R. C.; Shih, H. C.; Hsieh, Y. L.; Chen, U. Y. \& Hsu, C. Prenatal exposure of testosterone prevents SDN-POA neurons of postnatal male rats from apoptosis through NMDA receptor. $J$. Neurophysiol., 86(5):2374-80, 2001.

Licht, R. W.; Larsen, J. O.; Smith, D. \& Braendgaard, H. Effect of chorionic lithium treatment with or without haloperidol on number and sizes of neurons in rat neocortex. Psychopharmacology (Berl.), 115(3):371-4, 1994.

Marín-Padilla, M. Neuropathologic correlates of perinatal asphyxia. Int. Pediatrics, 15:221-8, 2000.
Meredith, G. E.; De souza, I. E.; Hyde, T. M.; Tipper, G.; Wong, M. L. \& Egan, M. F. Persistent alterations in dendrites, spines, and dynorphinergic synapses in the nucleus accumbens shell of rats with neuroleptic induced dyskinesias. J. Neurosci., 20(20):7798$806,2000$.

Mitchell, I. J.; Cooper, A. C; Griffiths, M. R. \& Cooper, A. J. Acute Administration of haloperidol induces apoptosis of neurons in the stratium and substantia nigra in the rat. Neuroscience, 109(1):8999, 2002.

Noh, J. S.; Kang, H. J.; Kim, E. Y.; Sohn, S.; Chung, Y. K.; Kim, S. U. \& Gwag, B. J. Haloperidol-induced neuronal apoptosis: role of p38 and c-Jun-NH(2)-terminal protein kinase. J. Neurochem., 75(6):2327-34, 2000.

Post, A.; Almeida, O. F. X. \& Holsboer, F. Signal Pathways Mediating Antidepressant and Antipsychotic Drugs on Neuronal Cell Survival. Curr. Med. Chem. - Central Nervous System Agents, 4(2):105-18, 2004.

Post, A.; Rücker, M.; Ohl, F.; Uhr, M.; Holsber, F.; Almeida, O. F. \& Michaeliditis, T M. Mechanism underlying the protective potential of vitamin E against Haloperidol-associated neurotoxicity. Neuropsychopharmacology, 26(3):397-405, 2002.

Roberts, R. C.; Force, M. \& Kung, L. Dopaminergic synapses in the matrix of the ventrolateral striatum after chronic haloperidol treatment. Synapse, 45(2):78-85, 2002.

Wei, Z, Mousseau, D. D.; Dai, Y.; Cao, X. \& Li, XM. Haloperidol induces apoptosis via the sigma2 receptor system and Bcl-XS. Pharmacogenomics J., 6(4):279-88, 2006.

\section{Correspondence to:}

Ali Ghanbari

Fertility and Infertility Research Center

Kermanshah University of Medical Sciences

Kermanshah, P.O. Box 1568

IRAN

Received: 20-06-2013

Accepted: 20-10-2013

Email: aghanbari@kums.ac.ir 